\title{
EPHB6 wt Allele
}

National Cancer Institute

\section{Source}

National Cancer Institute. EPHB6 wt Allele. NCI Thesaurus. Code C150224.

Human EPHB6 wild-type allele is located in the vicinity of $7 q 34$ and is approximately $16 \mathrm{~kb}$ in length. This allele, which encodes ephrin type-B receptor 6 , is involved in the modulation of ephrin-B signaling. 